Seção Livre 



\title{
O caso da canoa incendiada: perfis e relações de pescadores em Salvador (1853-1880)
}

\author{
Rafael Davis Portela*
}

Resumo: Este artigo é uma versão modificada de parte da minha Dissertação de Mestrado. Nele, trato dos pescadores de Salvador na segunda metade do século XIX, lançando mão de documentação de fontes diversas para tentar traçar um perfil desses trabalhadores no que se refere à idade, cor, estado civil, renda, bem como aspectos de sua prática pesqueira: tipo de embarcação prevalecente, formas e arranjos de pesca. Usei como fio condutor do artigo a história de Francisco Xavier de Santana, pescador da povoação do Rio Vermelho, que por alguns anos teve que driblar uma série de ataques e sabotagens contra ele dirigidos para poder fazer sua pescaria com redes. Durante a análise dos sentidos do caso, procuro articular os dados gerais sobre os pescadores com as suas práticas para entender as lógicas das suas relações, suas conexões políticas e redes de amizade e solidariedade.

Palavras-chave: pescadores; Salvador (BA); século XIX.

Abstract: This article is a modified version of my Master's thesis. Here, I research thefishermen in Salvador in the second half of $19^{\text {th }}$ century, using different sources to draw a profile of these workers, with data about age, race/color, civil status, income, as well as aspects of their fishing practice, the kind of boats they used, and work arrangements. I also analyze the case of Francisco Xavier de Santana, a fisherman from Rio Vermelho district, who had to struggle for a few years against personal attacks and sabotages to fish with his fishing net. I seek to combine the general data about fishermen and their practices to understand the logic of their personal and work relations, their political connections and their networks of friendship and solidarity.

Keywords: fishermen; Salvador (BA); 19th century.

A pescaria era atividade usual na Bahia oitocentista. O censo geral de 1872, tido como a contagem mais confiável disponível para o século XIX, aponta um total de 4.633 pescadores em toda a província. A Bahia é de longe a que tem a maior

* Agradeço ao CNPq, por ter financiado esta pesquisa, aos pareceristas desta revista por suas sugestões e aos colegas da linha de pesquisa Escravidão e Invenção da Liberdade, pela leitura rigorosa, contribuições e críticas. 
quantidade, seguida por Maranhão (2.450) e Pernambuco (2.185), que juntos praticamente igualam o número baiano. Para se ter uma noção do que isso representava, a Bahia respondia sozinha por $20 \%$ dos pescadores do império, mais do que as províncias do Amazonas, Piauí, Paraíba, Sergipe, Espírito Santo, São Paulo, Paraná, Rio Grande do Sul, Minas Gerais, Goiás e Mato Grosso somadas. ${ }^{1}$

Esse elevado número de pescadores não chega a surpreender. A Bahia tem o maior litoral do Brasil, incluindo o arquipélago de Abrolhos, considerado o melhor pesqueiro do litoral brasileiro, e duas das três maiores baías do país - a de Camamú, a terceira, e a de Todos os Santos, a primeira. Esta foi objeto de admiração quase que obrigatório por parte dos visitantes que pela Bahia passaram, não só pela sua extensão e beleza, mas pela variedade e abundância de sua vida marinha.

Mas a atividade pesqueira não era uniformemente distribuída ao longo desse vasto litoral, ela acompanhava os núcleos habitacionais, com longos espaços praticamente inabitados intervalando os locais com concentração populacional. Além disso, a geografia marítima de alguns lugares tornava-os mais apropriados para a pesca do que outros. Além de Abrolhos, destacavam-se Canavieiras, Barra do Rio de Contas, Valença, Ilha de Itaparica e Salvador como regiões de pesca.

Capital e cidade mais importante da província, Salvador possuía na segunda metade do século XIX um bom número de pescadores, que são aqui meu objeto de estudo. Neste artigo, após um breve mapeamento das regiões de pesca da capital, busquei compor quadros com características gerais dos pescadores da cidade, como média de idade, estado civil e renda. ${ }^{2}$ Junto a eles um estudo de caso envolvendo pescadores do Rio Vermelho para desenhar um perfil desses trabalhadores e entender algumas lógicas de suas relações.

Uma importante fonte para o estudo de trabalhadores no século XIX são as listas de qualificação eleitoral. Como não havia na época algo como um título de eleitor, toda vez que houvesse eleições era preciso que fossem formadas juntas de qualificação nas quais os cidadãos se credenciariam a participar do processo eleitoral, tendo seus dados arrolados em uma lista. A depender de cada junta, mais ou menos informações eram recolhidas, sendo nome, idade, estado civil e profissão imprescindíveis. A partir daí, pude fazer uma listagem separando somente os pescadores das diversas juntas com mais de 700 pescadores no banco de dados. Trata-se de uma amostragem com boa representatividade, correspondendo a $16 \%$ do número de pescadores da época. Contudo, estavam sumariamente eliminados do processo de votação (e, portanto, das listas) os que tinham abaixo de 25 anos (para casados e oficiais militares o mínimo era de 21 anos), africanos e escravos. Além disso, as listas de que lancei mão se limitam às regiões urbanas e suburbanas da capital.

1 Comparando os dados do censo com os registros de matrículas da Capitania dos Portos, estimo que a Bahia chegou a ter no ano de 1864 cerca de 6.600 pescadores. Este número demoraria a ser superado. Em 1922, existiam apenas 3.407 pescadores matriculados. Hoje, já são cerca de 100.000. Recenceamento Geral do Brazil em 1872, Censo de 1872. http://biblioteca.ibge.gov.br/ visualizacao/monografias/GEBIS - RJ/Recenseamento_do_Brazil_1872/Imperio do Brazil 1872.pdf Acesso em 22/03/2012. BRASIL: Ministério da Marinha, Relatório apresentado à Assembleia Geral. Biblioteca Pública do Estado da Bahia (BPEB), "Capitania do Porto da Bahia", s/a, in Diário Oficial do Estado da Bahia: Edição especial do centenário, Ano 8, 02/07/1923, p. 344-5; e Bahia Pesca http://www.bahiapesca.ba.gov.br/?page $\mathrm{id}=5$. Acesso em 22/03/2012. Detalhes sobre a variação do número de pescadores da província durante a segunda metade do século XIX em PORTELA, Rafael. "Pescadores na Bahia do Século XIX”. (Dissertação de Mestrado, Universidade Federal da Bahia, 2012).

2 Por vezes neste artigo, na ausência de informações específicas para a cidade de Salvador, foi preciso recorrer a dados referentes à Bahia como um todo, como os produzidos pela Capitania dos Portos ou o censo nacional. 
As juntas eram organizadas por freguesias, tradicional divisão administrativa e religiosa das cidades, cada uma ligada à sua igreja matriz, onde se registravam batizados, óbitos e casamentos. ${ }^{3}$ Das onze freguesias urbanas, foi possível encontrar listagem em dez, faltando a do Paço. Das sete suburbanas, cinco foram localizadas, exceto Pirajá e Cotegipe.

Tabela 1 - Pescadores e total de qualificados nas Listas Eleitorais (1853-1880)

\begin{tabular}{ccc} 
Freguesias & Qualificados & Pescadores \\
\hline Itapuã (sub.) & 433 & $194(44,8 \%)$ \\
\hline Ilha de Maré (sub.) & 307 & $174(56,7 \%)$ \\
\hline Vitória (urb.) & 686 & $106(15,5 \%)$ \\
\hline Penha (urb.) & 583 & $95(16,3 \%)$ \\
\hline Brotas (urb.) & 904 & $56(6,2 \%)$ \\
\hline Matoim (sub) & 191 & $31(16,2 \%)$ \\
\hline Paripe (sub.) & 275 & $29(10,5 \%)$ \\
\hline Passé (sub.) & 622 & $17(2,7 \%)$ \\
\hline Conceição da Praia (urb.) & 454 & $9(2,0 \%)$ \\
\hline Total & 4455 & $711(16 \%)$ \\
\hline
\end{tabular}

Fonte: AHS e APEBa, Listas Eleitorais.

Nas listagens das freguesias de Santana, São Pedro, Sé, Santo Antônio, Mares e Pilar - todas elas urbanas - não há pescadores. As duas últimas eram as únicas que abrangiam território na orla da cidade. Por outro lado, todas as freguesias com pescadores possuíam o seu quinhão do mar. Vejamos o caso da Nossa Senhora da Conceição da Praia, onde ficava o porto principal da cidade, freguesia litorânea em toda a sua extensão, espremida entre as montanhas e o mar, com distância máxima de 110 metros. Fazendo fronteira com o Pilar de um lado e a Vitória do outro, sua extensão de pouco mais de um quilômetro estava recortada em nove quarteirões. Pois dos nove pescadores registrados, que representam apenas $2 \%$ dos qualificados da freguesia, oito moravam em um mesmo quarteirão, o segundo, onde eram 14\% dos listados. Esse quarteirão está localizado na comunidade das Pedreiras, vizinha à praia da Gamboa de Baixo.

No outro extremo temos Brotas, gigantesca freguesia que se iniciava na Barros Reis, onde fazia fronteira com Santo Antônio Além do Carmo, passava pelo Dique, onde encontrava as freguesias de Santana e São Pedro, alcançava a ponta da Mariquita para dividir limites com a freguesia da Vitória, contornava a lagoa da Pituba até chegar ao Rio das Pedras, a partir de onde se iniciava a freguesia de Itapuã. Essa freguesia com extensão digna de uma cidade média da época, relativamente despovoada e com muitos territórios caracteristicamente rurais estava subdivida em vinte e três quarteirões, mas seus 56 pescadores somente aparecem em seis deles, sendo que 46 estavam concentrados nos últimos três quarteirões, localizados no povoado do Rio Vermelho. Em um deles, $023^{\circ}$, mais de dois terços dos trabalhadores eram pescadores.

As demais freguesias trazem resultados semelhantes, mas não convém ser repetitivo. O que importa aqui é ver que, apesar de possuir uma orla enorme, 90\%

3 NASCIMENTO. Dez freguesias, p. 44-6. 
dos pescadores da capital estavam concentrados na Ilha de Maré, Itapagipe, Itapuã, na faixa litorânea do Unhão até a Barra e no Rio Vermelho - e em partes específicas dessas regiões, como acabamos de ver. ${ }^{4}$ Essa realidade gerava nas autoridades a sensação de um desperdício de potencial. Em 1857, o capitão do porto Diogo Ignácio Tavares se queixava da pesca continuar a ser feita "da maneira mesquinha de costume, [...] limitando-se a sua pescaria a um pequeno número de embarcações dos portos vizinhos que fazem uma pescaria insuficiente para as necessidades dos seus habitantes", ${ }^{5}$ apontando uma tendência da pescaria oitocentista, o costume de se pescar próximo de onde se vive e para subsistência, sobretudo. 0 predomínio de embarcações típicas de curtos deslocamentos comprova isso.

Tabela 2 - Embarcações utilizadas por pescadores, 1861

\begin{tabular}{cccc}
\hline Tipo de embarcação & $\begin{array}{c}\text { Quantidade de } \\
\text { embarcações }\end{array}$ & $\begin{array}{c}\text { Pescadores } \\
\text { empregados }\end{array}$ & \% pescadores \\
\hline Canoas & 1.437 & 3.578 & 92,6 \\
\hline Baleeiros & 24 & 237 & 6,1 \\
\hline Botes & 31 & 48 & 1,2 \\
\hline Total & 1.492 & 3.863 & 100 \\
\hline
\end{tabular}

Fonte: Relatório do Ministério da Marinha, 1861.

Os pescadores tendiam não apenas a morar próximo de onde trabalhavam, mas perto também uns dos outros, compondo verdadeiras vilas de pescadores. Construíam, portanto, relações entre eles que ultrapassavam a esfera do trabalho. A análise do caso de Francisco Xavier de Santana será útil para entendê-las.

\section{Vilipendiado, extorquido e esmagado}

Francisco Xavier de Santana era um pescador do povoado do Rio Vermelho que se envolveu numa longa contenda com alguns colegas de ofício da região. Hoje o Rio Vermelho é internacionalmente conhecido como principal ponto da festa de lemanjá do dia 2 de fevereiro, quando pescadores e uma multidão de adeptos do Candomblé, Umbanda e do catolicismo fazem cortejo e levam oferendas para a Rainha do Mar. Na segunda metade do século XIX, o Rio Vermelho já era um tradicional ponto de pesca, com uma importante colônia de pescadores.

Por alguns anos, Xavier foi alvo de impedimentos diversos ao exercício de sua atividade pesqueira, desde ofensas verbais a arbitrariedades jurídicas e

4 Arquivo Histórico de Salvador, Listas Eleitorais 1828-1893 (Paróquia de Nossa Senhora da Conceição da Praia - 1876; Paróquia de Itapuã - 1880; Paróquia de Santana - 1876; Paróquia da Sé - 1876; Paróquia de São Pedro - 1876); Livro 116 - Listas Gerais de Votantes da Paróquia de Brotas - 1879; Livro 592 - Qualificação da Freguesia da Penha de Itapagipe - 1859-1875; Livro 619 - Junta de Qualificação dos Votantes da Freguesia da Vitória - 1880; Livro 620 - Qualificação da Freguesia do Passé - 1880; APEBa, Correspondência Recebida da Junta de Qualificação, maço 2830 - Qualificação da Freguesia de Santana da Ilha de Maré - 1865; maço 2830 - Qualificação da Freguesia de Nossa Senhora do Matoim - 1870; maço 2814 Qualificação da Freguesia do Pilar - 1859; maço 2830.1 - Qualificação da Freguesia dos Mares - 1874; maço 2807 - Qualificação da Freguesia de Santo Antônio Além do Carmo - 1853. Daqui por diante, referirei-me ao conjunto como "Listas Eleitorais". Por Salvador, refiro-me aqui ao espaço administrativo da capital, com suas freguesias urbanas e suburbanas, estando excluída, por exemplo, a Ilha de Itaparica. Agradeço a Aldrin Castellucci por ter indicado essa documentação, fundamental para a pesquisa.

5 Arquivo Nacional, XM-183, Relatório da Capitania do Porto da Bahia, 02/01/1857. 
sabotagens materiais. Segundo ele, os conflitos se iniciaram em 1856, quando decidiu substituir a pesca de linha pela de rede, esperando "colher melhor resultado" no provimento de si e de sua família. "Dispôs-se pois a grande dispêndio em sua factura, a compra de uma canoa e mais aprestos que se tornaram de mister". Para resolver os requisitos materiais, havia antes os burocráticos, dentre eles o que mais traria dor de cabeça a Xavier nos anos seguintes, a questão da bitola da rede. ${ }^{6}$

Para ser lançada ao mar, uma rede precisava de licença, que só era concedida após pagamento das taxas correspondentes e análise da sua bitola, nome que se dá ao tamanho da malha. Quanto menor for esta, menores os peixes que a rede é capaz de capturar. Daí o controle por parte da Câmara, tentativa de evitar a pesca de filhotes de peixes comprometendo a sua reprodução. A Câmara possuía bitolas que serviam de molde para a feitura das redes, somente recebendo licença aquelas que possuíssem bitola igual ou maior. A bitola variava de tamanho, a depender de cada parte da rede. Diz o manual: "Há [ ] três espécies de malha. A maior chama-se 'manga', e está colocada nas extremidades da rede, onde puxam as cordas; seguem-se as malhas intermediárias chamadas 'encontros', que ficam juntos à manga de um e outro lado; por fim o 'cópe', que é a malha mais estreita, e é a que fica no centro". 7

No dia 21 de julho de 1856, Francisco Xavier solicitou ao presidente da Câmara o molde, tendo este repassado ao padre Amaral que, por fim, encaminhou ao fiscal claviculário Antônio Coelho no dia 29. Onze dias depois a rede estava pronta e conferida, mas somente no dia 22 de outubro sairia a liberação final, custando ao pescador 90 dias e cinco mil réis. Durante esse tempo, Xavier matriculou-se na Capitania do Porto, encerrando seus dias de pesca clandestina. Quem sabe a pesca de rede fosse mais visível, sendo mais perigoso exercê-la irregularmente do que a pesca de linha.

Licença obtida, partiu Xavier a executar sua pescaria. Foi quando os seus problemas começaram. De acordo com o seu relato, ele "se viu vilipendiado, extorquido e esmagado em seu direito pelos pescadores do porto de Sant'Anna do Rio Vermelho". Seguiram-se "graves e constantes desordens" a fim de impedi-lo de lançar sua rede naquela povoação. Intimidações verbais e ameaças fizeram parte já dos seus primeiros dias, quando pôde ver claramente que os pescadores locais estavam convencidos de que ele não teria o direito de pescar por lá e que estavam dispostos a se mobilizar para garantir que isso não ocorresse. Talvez não imaginasse a que ponto.

Descobriria numa manhã de domingo, dia 4 de dezembro de 1861, cinco anos após ter obtido sua licença. Ao chegar à praia encontrou sua canoa partida ao meio, incendiada e infensa a qualquer tipo de remendo; mesmo destino teve sua rede de pesca, guardada dentro do que restou da embarcação. ${ }^{8}$

6 APEBa, correspondência recebida de diversos pescadores e da Sociedade de Pesca, maço 4634, Petição de Francisco Xavier de Santana ao presidente da província, 31/08/1863.

7 BAHIA. "A pesca na Bahia”, s/a, in Diário Oficial do Estado da Bahia: Edição especial do centenário. Salvador: Biblioteca Pública do Estado da Bahia (BPEB), Ano 8, 02/07/1923, p. 191. A Câmara Municipal estabelecera em 1855 que as dimensões do copio e encontro deveriam ser de, no mínimo, uma polegada e o da manga uma polegada e meia. Na mesma seção, deliberara que o Sr. Pe. Amaral fosse encarregado de dar as bitolas. $\mathrm{O}$ porquê da presença de um padre na conferência das bitolas é ainda um mistério a ser desvendado. APEBa, correspondência recebida de diversos pescadores e da Sociedade de Pesca, maço 4634, Edital, 28/03/1863.

8 APEBa, Petição de Francisco Xavier de Santana ao presidente da província, 31/08/1863. APEBa, correspondência recebida de diversos pescadores e da Sociedade de Pesca, maço 4634; comprovante de matrícula de Francisco Xavier de Santana, 03/10/1856. APEBa, correspondência recebida de diversos pescadores e da Sociedade de Pesca, maço 4634; solicitação do secretário da Câmara ao presidente da Câmara, 1/09/1863. 
Parênteses. Francisco Xavier tinha por volta de 49 anos em 1861. Filho de Joaquim José de Santana e de Joana Maria do Nascimento, Xavier era um pardo de olhos castanhos e cabelos crespos. Foi descrito como tendo rosto oval, nariz "regular", tinha pouca barba na ocasião da sua matrícula e media aproximadamente 1,65 m de altura. Além dele, outros tantos pardos exerciam a profissão pesqueira na Bahia, numericamente superados apenas pelos pretos, como vemos na Tabela 3.

Tabela 3 - Pescadores na Bahia por cor em 1861

\begin{tabular}{c|c|c|c|c}
\hline Cor & Livres & Escravos & Total & $\begin{array}{c}\% \text { de homens adultos } \\
\text { (censo 1872) }\end{array}$ \\
\hline Brancos & $1.249(38 \%)$ & 0,00 & $1.249(29 \%)$ & $28 \%$ \\
\hline Índios & $100(3 \%)$ & 0,00 & $100(3 \%)$ & $4 \%$ \\
\hline Pardos & $1.193(36 \%)$ & $185(17 \%)$ & $1.378(32 \%)$ & $46 \%$ \\
\hline Pretos & $739(23 \%)$ & $903(83 \%)$ & $1.642(38 \%)$ & $22 \%$ \\
\hline Total & $3.281(100 \%)$ & $1.088(100 \%)$ & $4.369(100 \%)$ & $100 \%$ \\
\hline
\end{tabular}

Fonte: Relatórios do Ministério da Marinha e IBGE.

Tabela 4 - Pescadores por faixa etária

\begin{tabular}{c|c}
\hline Faixa Etária & Porcentagem \\
\hline 30 ou menos & $22,5 \%$ \\
\hline 31 a 35 & $12,0 \%$ \\
\hline 36 a 40 & $14,0 \%$ \\
\hline 41 a 45 & $12,9 \%$ \\
\hline 46 a 50 & $14,0 \%$ \\
\hline 51 a 55 & $8,6 \%$ \\
\hline 56 a 60 & $5,4 \%$ \\
\hline 61 a 65 & $4,7 \%$ \\
\hline 66 ou mais & $5,7 \%$ \\
\hline
\end{tabular}

Fonte: Listas Eleitorais, 1853-1880.

Comparando-se os pescadores com a população como um todo (vide campo "\% de homens adultos" da Tabela 3), ${ }^{9}$ vemos que pretos estavam super-representados entre os pescadores, enquanto que pardos estavam sub-representados. Confirma a ideia da pesca como trabalho de pretos, o qual pardos, por terem meIhores possibilidades na sociedade, tentariam evitar. Curiosamente, brancos não pareciam fugir desse ofício típico de pretos, visto que sua proporção na pesca é quase idêntica à sua na sociedade. A pesca era uma atividade com alto grau de autonomia, o que podia ser um atrativo também para brancos, principalmente os pobres. E havia uns poucos que conseguiam ascender socialmente através dela, como veremos mais à frente. ${ }^{10}$

9 Para comparar os dados dos pescadores com a população baiana como um todo, foi preciso comparar dados de anos diferentes, visto não haver para o mesmo ano. As porcentagens do campo "percentual de homens adultos" foram retiradas de IBGE, Recenceamento Geral do Brazil em 1872.

10 Durante boa parte do século XIX, o termo preto foi utilizado como sinônimo de africano, enquanto que crioulos eram aqueles de pele escura nascidos no Brasil. Aproximando-se o seu término, o termo preto 


\section{Gráfico 1 - Estado civil dos pescadores}

Fonte: Listas Eleitorais, 1853-1880.

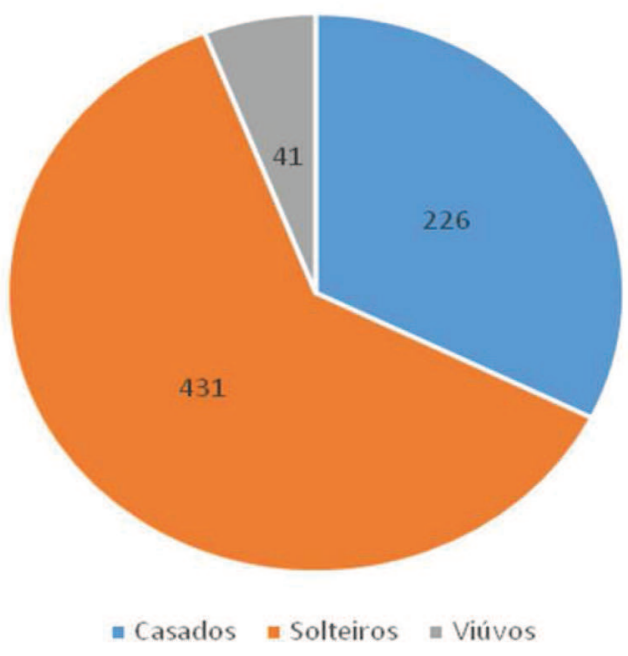

Apesar de não ser mais um moço, aos 49 anos Francisco Xavier não podia ser considerado velho para a sua profissão. Sua faixa etária era ainda bastante representativa na pescaria. Estes dados mostram também que, embora a faina marítima fosse desgastante, um número razoável de pescadores continuava nela mesmo com o avançar da idade, com cerca de $38 \%$ com 46 anos ou mais. Xavier costumava dizer que era responsável pelo sustento de uma "numerosíssima família", o que não chegava a ser mentira, talvez exagero. Era casado com Apolinária Maria de Santana, com quem teve cinco filhos: Geraldo Xavier de Santana, Agripina Maria de São José, Maria dos Passos, Alexandrina Maria de Santana, e o caçula, que herdou o nome do pai. Eram todos livres e nada indica que algum deles tivesse sido escravo em qualquer época. Assim como Xavier, a maior parte dos pescadores por toda a metade do século XIX era livre, como vemos no Gráfico $1 .{ }^{11}$

\section{Gráfico 2 - Condição civil dos pescadores}

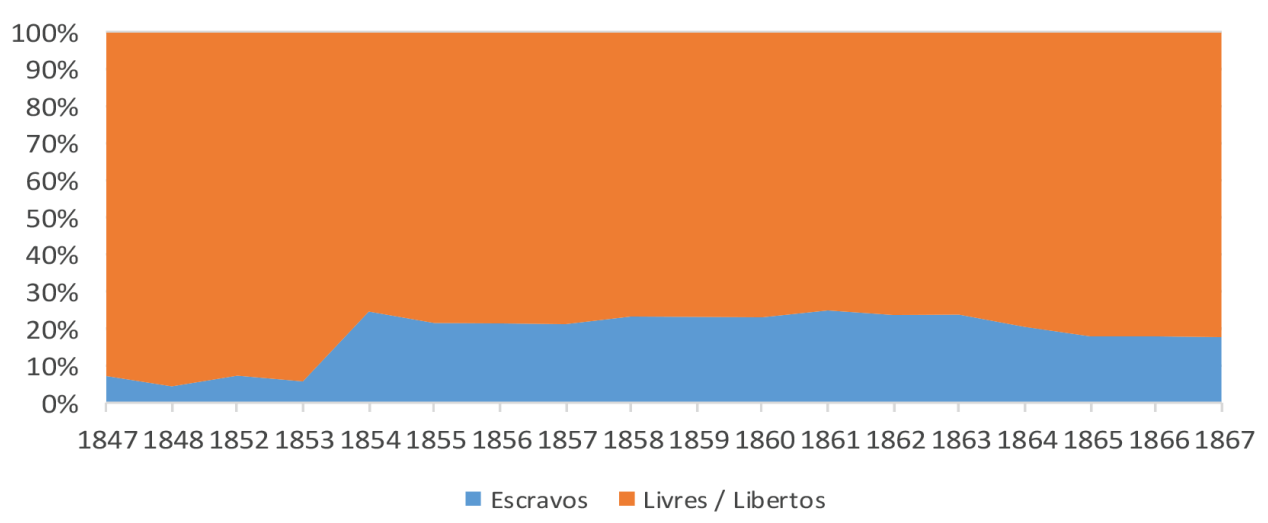

Fonte: Relatórios do Ministério da Marinha, 1847-1867.

passa a valer para negros brasileiros e africanos, o que João Reis sugere ser um indício da adaptação da sociedade para viver com apenas um tipo de negro, o brasileiro. Este teria sido de certo modo "africanizado" no sistema de classificação racial. REIS, João. "De olho no canto: trabalho de rua na Bahia na véspera da Abolição”, Afro-Ásia, 24 (2000), pp. 232-3. A Capitania dos Portos parece ter se adiantado nesse processo, já que desde os primórdios dos seus trabalhos (1846), procedia com esse tipo de classificação.

11 APEBa, solicitação do secretário, 01/09/1863. APEBa, Série Inventário, Estante 3, Caixa 1280, Maço 1749, Documento 7, Inventário de Apolinária Maria de Santana, 01/09/1869. In: BRASIL: Ministério da Marinha, Relatório apresentado à Assembleia Geral, 1848 a 1867. 
É importante observar a evolução do contingente de cativos entre os pescadores da capitania porque o percentual de escravos na Bahia variou durante o século XIX. A tendência, que era de crescimento no início do século, passa a se inverter, especialmente após 1850, com o fim do tráfico transatlântico. No censo de 1872, a Bahia aparece com uma proporção de 12\% de escravos em sua população, valor que diminuiria vertiginosamente até a véspera da abolição. ${ }^{12}$

O que nos dizem os dados da capitania? Percebe-se de imediato a falta da discriminação entre livres e libertos. Assim como o censo de 1872, a Capitania dos Portos não se preocupou em separar nos seus dados as pessoas livres de nascença dos que foram um dia escravos e lograram se emancipar. Este é um dado curioso, visto que a capitania se preocupava em registrar dados bastante específicos como o formato do rosto e do nariz, mas omitia uma distinção que era fundamental para as regras sociais da época, com consequências jurídicas e simbólicas.

Até o ano de 1854, pouco podemos confiar nos dados da capitania por não incluir parte considerável dos pescadores. Daí porque, até esse ano, a proporção de escravos apareceu como bastante baixa - tudo indica que a prioridade nas matrículas eram os não escravos, o que se encaixa no objetivo da capitania de compor com os matriculados sua reserva para a Marinha de Guerra, para o que livres e libertos eram o alvo principal. ${ }^{13}$

O maior declínio da população escrava em Salvador foi decorrência direta da Guerra do Paraguai, que os escravos foram lutar por diversos modos. Uns poucos senhores, que desejavam contribuir com a causa, cederam escravos para as forças armadas; outros, menos patrióticos, enviaram seus cativos como substituição para a sua própria convocação ou a de seus filhos, ou simplesmente os venderam para o exército; alguns escravos foram diretamente recrutados pelo governo e outros fugiram para o exército na esperança de se tornarem livres ao fim da guerra. Até 1869, há o registro do envio de 1.647 escravos da Bahia, mas o número real deve ter sido maior. ${ }^{14}$

A partir de 1867 , deixamos de contar com os dados da capitania, mas é de se acreditar que o número de escravos na pesca tivesse mantido seu declínio progressivo. Um dos fatores que certamente contribuiu foi o tráfico interno, que existia desde o século XVII, mas intensificou-se após o encerramento do comércio transatlântico. A tendência era de saída de cativos das decadentes áreas açucareiras do Nordeste para as novas e prósperas economias cafeeiras do Sudeste. Estima-se que 200 mil foram vendidos entre 1850 e 1881, ano em que foram criados fortes impostos para inviabilizar este comércio. Só do Nordeste teriam saído 90 mil escravos, perto de 3 mil por ano. ${ }^{15}$

A comercialização não era apenas interprovincial. Ao contrário das demais regiões açucareiras do Norte, que desde a década de 1850 iniciaram a transição da sua mão de obra escrava para a livre, os grandes proprietários do Recôncavo se mantiveram dependentes da mão de obra servil "até a véspera" - uma das causas da

12 MATTOSO, Kátia M. de Queirós. Bahia, Século XIX: uma província no Império. Rio de Janeiro: Nova Fronteira, 1992, p. 86 e 94; IBGE, Recenceamento Geral do Brazil em 1872.

13 A imprecisão dos mapas até 1854 tornou impossível perceber o impacto da epidemia do cólera na proporção de escravos entre os pescadores. Segundo David, a proporção de mortos para Salvador foi de $51,9 \%$ de livres, $15,7 \%$ libertos e 32,4\% escravos, tornando os escravos ligeiramente sobrerepresentados entre os falecidos. DAVID. O inimigo invisível, p. 152. Naquele ano, $27,5 \%$ da população de Salvador era escravizada, de acordo com Nascimento, Dez freguesias, p.164.

14 RODRIGUES. Os (in)voluntários da pátria, capítulo 3. Sobre o número de escravos, p.117. O autor considera ser impossível calcular um número exato de escravos participantes da guerra.

15 GRAHAM, Richard. "Nos tumbeiros mais uma vez: o comércio interprovincial de escravos no Brasil”, AfroÁsia, 27 (2002), p.122. 
ruína quase total da economia açucareira baiana no pós-abolição. Tornou-se menos provável a presença de escravos em atividades menos pujantes economicamente, como a pesca, diante da sede por mão de obra de setores mais fortes da economia. ${ }^{16}$

Em 1872, essa participação já era um tanto baixa: apenas $6 \%$ dos pescadores eram cativos. Ainda mais que escravos representavam naquela época $12 \%$ do total de homens da província, o dobro de sua proporção entre os pescadores, portanto. ${ }^{17} \mathrm{Em}$ suma, temos na pesca baiana da segunda metade do século XIX uma participação escrava que variou, tendendo a um progressivo declínio. Mesmo no seu auge, os escravos foram minoria absoluta, ainda que significativa, representando apenas um quarto da mão de obra pesqueira. Não era, portanto, uma atividade tipicamente escrava, seja em termos absolutos ou relativos.

Voltemos às cinzas do equipamento de Xavier. O incêndio ocorrera na praia do Porto da Paciência, local onde Francisco Xavier cotidianamente pescava e, à noite, deitava a canoa na praia. A praia estava a poucas centenas de metros de distância do Largo da Mariquita, onde ele residia. No dia seguinte, Xavier foi à subdelegacia prestar queixa e solicitar exame de corpo de delito, realizado poucas horas depois. Os peritos encontraram popa e proa da canoa separadas, o centro consumido pelo fogo. Estimaram que ela teria, quando inteira, cinquenta e cinco palmos de comprimento (aproximadamente 12 metros), com três palmos e meio de boca (perto de 80 centímetros). Analisaram os restos da rede incendiada e, segundo o escrivão, era rede conhecida deles, feita de barbantinho, ${ }^{18}$ medindo cem braças de comprimento (mil palmos ou, aproximadamente, 220 metros) e quatro braças e meia de altura (aproximadamente 10 metros). Vê-se que o equipamento não era dos pequenos. Tal foi a opinião dos peritos, que arbitraram o prejuízo em seiscentos mil réis, o equivalente a mais de cem alqueires de farinha, ou dois terços do preço de um escravo saudável do sexo masculino no serviço da lavoura. Valor nada irrisório para as contas de um pescador, como veremos mais à frente. ${ }^{19}$

A destruição do equipamento de pesca de Xavier decerto era modo eficaz de impedir sua pesca, como admitiu o próprio, ao dizer que "[os pescadores do Rio Vermelho] julgaram afinal que [ ] o melhor meio que tinham de lançar mão contra o Representante era o de lançar fogo a sua rede e canoa". ${ }^{20} \mathrm{~A}$ importância dos equipamentos de pesca para o sustento dos pescadores era tamanha que se criava com eles um componente sentimental. Assim o era para Anselmo, pai de Jana, personagens da novela oitocentista Jana e Joel, do baiano Xavier Marques. O mestre pescador

nunca suporia perdido o tempo gasto a perscrutar as nuvens, em defesa do seu lindo barco, o barco do ganho, que lhe dava o sustento e recebia, por isso, uma pensão de amor e desvelos nem maior nem menor que a parte da velha Teó [sua mãe] e de cada um dos filhos. Tritão entrava assim no lote da família, como um parente benfeitor, por cuja salvação fazia preces a velhota rezadeira, quando os temporais o apanhavam longe do porto, a fretejar. ${ }^{21}$

16 BARICKMAN, B. J. "Até a véspera: o trabalho escravo e a produção de açúcar nos engenhos do Recôncavo baiano (1850-1881), Afro-Ásia, 21-22 (1998-1999), pp.181-183.

17 IBGE, Recenceamento Geral do Brazil em 1872.

18 Espécie de cordão forte.

19 APEBa, correspondência recebida de diversos pescadores e da Sociedade de Pesca, maço 4634; exame de corpo de delito solicitado por Francisco Xavier de Santana, 05/12/1861; sobre o preço dos escravos e da farinha, BARICKMAN, B. J. Um contraponto baiano: açúcar, fumo, mandioca e escravidão no Recôncavo, 1780-1860, Rio de Janeiro, Civilização Brasileira, 2003, p. 232-234.

20 APEBa, Petição de Francisco Xavier de Santana ao presidente da província.

21 MARQUES, Xavier. "Jana e Joel” in Praieros, Brasília, GRD, 1983, p. 5 e 6. Grifo no original. 
Portanto, os opositores de Xavier atacaram onde mais doía, ato que pode ter sido também simbólico. Ainda assim, ele não tomou outra atitude além da solicitação do corpo de delito; ele próprio diria no futuro que se não fez nada foi por temer pela própria vida. O incêndio pareceu ter cumprido, ao menos temporariamente, um dos objetivos: aterrorizar o pescador.

Com seu principal meio de produção destruído, Francisco Xavier passou uns tempos fora de combate, mas não desistiria da empresa. Com o tempo, construiu novas canoa e rede. Em fevereiro de 1863, passado pouco mais de um ano da destruição de sua primeira canoa, já estava na ativa, tendo repetido o procedimento burocrático junto à Câmara. Pouco tempo depois recebeu ordem do subdelegado da Vitória para que interrompesse a pescaria no Rio Vermelho, já que havia representação feita contra ele por "alguns moradores" da povoação, acusando-o de atuar de modo irregular. Este foi o início de uma inflexão no comportamento dos seus oponentes, que a partir daí priorizariam pressões jurídicas a confrontos diretos.

Francisco solicitou formalmente ao chefe de polícia que cessasse a proibição daquele "legítimo" trabalho, que "não pode resultar prejuízo" e servia de "subsistência para si e para a sua numerosíssima família", sendo também "tão vantajoso e necessário a toda aquela povoação". Pesaram mais do que esses apelos os argumentos de que nenhuma razão legal havia para vedar aquele "lícito ato" e que "nenhuma Lei ou Postura proíbe o pescar com rede no litoral, mar livre". A solicitação foi parar na Câmara, que desta feita informou que não havia bitola para as redes e sugeriu ao subdelegado que consentisse com o apelo do pescador. Tudo indica que a prática de se medir a bitola ficara para o passado. ${ }^{22}$

Se, em fevereiro de 1863, foi possível pra Francisco Xavier argumentar não haver lei ou postura que o proibisse de pescar, seus inimigos trataram de corrigir esta falta logo no mês seguinte. Nos dias finais de março, a povoação do Rio Vermelho amanheceu com cópias, pregadas nas paredes, de um edital da secretaria da Câmara Municipal que reeditava uma lei de 1855. Reproduzo aqui trecho relevante: "Fica proibido pescar-se em todo o litoral do Município com redes de arrasto, salvo se suas malhas forem marcadas pela bitola da Câmara: penas aos contraventores de trinta mil réis, (30\$000) e oito dias de prisão." A postura tinha sido reeditada pela Câmara no dia 28 de março e as cópias impressas na Tipografia de França Guerra. Logo nos dias seguintes, a licença de Francisco foi cassada com base na postura, o que mostra o grau de articulação política dos seus inimigos.

Já no mês seguinte, Francisco Xavier foi à Câmara solicitar mais uma vez licença para usar a rede e obteve-a sem que medissem a sua malha, mais um indício de que esta prática estava em desuso. Pouco adiantou, mais uma vez foi impedido de pescar pela polícia, novamente sob alegação de falta de bitola da Câmara. Diante do impasse entre os poderes públicos locais, Xavier entendeu que era hora de apelar para instâncias superiores.

Em 31 de agosto de 1863, escreveu longo texto ao presidente da Província detalhando todo o caso - que já completava oito anos - e reclamando dos abusos e ilegalidades cometidos contra ele pela Câmara Municipal e órgãos policiais. Preparou um dossiê com todos os documentos em sua posse e solicitou à Presidência que fizesse cessar as "arbitrariedades, abusos e despesas não autorizadas por lei". Procurou seguir três linhas de argumento que se repetiram ao longo do documento: mostrar que sua atividade era absolutamente fundamental para o sustento de sua

22 PEBa, Petição de Francisco Xavier de Santana ao presidente da província. APEBa, solicitação do secretário, 01/09/1863. 
"numerosíssima" família, bem como para toda a comunidade, que carecia de alimentos; apontar que a Câmara estava exigindo dele o que não exigia de nenhum outro pescador em nenhum outro ponto de pescaria - exigia inclusive aquilo que nem mesmo a ele fora exigido meses antes; e, por fim, procurou dar clara conotação política às decisões contra ele tomadas. A solicitação foi enviada pela Presidência à Câmara e depois foi parar na Comissão de Justiça, mas não localizei as respostas.

\section{Motivos e porquês}

Em suas queixas, Xavier dizia que o povo estava exacerbado contra ele "por espírito de inveja ou ambição". Difícil acreditar que um sentimento de inveja por si só pudesse ser capaz de mobilizar tanto e por tanto tempo. Inveja de quê, aliás?

Acreditava que fosse da sua condição financeira, penso. Xavier era um pescador com renda acima da média de sua categoria. Por outro lado, não era um exemplo de eficácia na economia doméstica, andava a dever bastante na praça. A bomba estourou em 1869, quando do falecimento de sua esposa Apolinária. Um de seus credores entrou na justiça exigindo o inventário das posses do casal para que a dívida fosse sanada. Tratava-se de Felix Vallois Garcia, liquidante da firma Conde \& Garcia. Houve uma certa demora no processo, pois estavam ausentes da cidade o filho caçula Francisco e Geraldo, agora vigário da freguesia da distante São José de Porto Alegre do Mucury, cidade do extremo sul da Bahia, que faz hoje fronteira com os estados de Minas Gerais e Espírito Santo, onde residia. A essa altura, estavam casadas Agripina e Maria dos Passos, entrando Pedro Francisco de Mello e Umbelino Gomes da Boa Morte na partilha dos bens como seus respectivos maridos.

$\mathrm{Na}$ listagem de bens do casal aparecem apenas terrenos e imóveis. Não possuíam pratarias, escravos ou móveis. Nem mesmo seus equipamentos de pesca, que já vimos não ser de baixo valor, aparecem. Quem sabe a presença cobiçosa dos credores tenha incentivado Xavier a discriminar tudo aquilo que não estivesse legalmente registrado em seu nome como pertencente aos filhos para que não fosse abatido na dívida e saísse das mãos da família.

Todas as propriedades estavam localizadas no Rio Vermelho e foram penhoradas para futura venda e quitação do débito, o restante a partilhar entre os herdeiros. Uma delas era a fazenda Dendezeiros da Mariquita, descrita como uma roça de dez braças de frente, (cerca de 22 metros), situada perto da ponte da Mariquita, contendo "poucos arvoredos". Podiam ser poucos, mas não era baixo seu valor. Os arvoredos sozinhos foram avaliados em 300 mil réis, enquanto o terreno em outros 400 mil réis. Dentro da roça, duas casas, uma pequena de taipa com uma porta e duas janelas, coberta com palha e outra de telha. Foram juntas avaliadas em 100 mil réis. A fazenda como um todo foi arrematada pelo então inquilino Laurentino Olímpio da Silva, que aumentou a avaliação inicial em 601 mil réis, desembolsando ao total 1:401\$000 (leia-se um conto, quatrocentos e um mil réis).

Havia ainda três outras casas. A maior delas era a de $n^{\circ} 832$, que usava como venda o inquilino Antônio Dias da Rocha, com 20 palmos de largura (cerca de quatro metros e meio) e duas portas à frente; tinha paredes dobradas de pedra e cal e foi avaliada em 800 mil réis. Antônio alugava por 14 mil réis por mês. Anexa a esta, havia uma casa que se encontrava fechada, tendo vinte e seis palmos e sete polegadas de frente (aproximadamente seis metros), com paredes de taipa e coberta de telha, estimada em 300 mil réis. Por último, uma pequena casa com 14 palmos (pouco mais de 3 metros) avaliada em 150 mil réis, alugada a Manoel Ni- 
colau da Conceição por 6 mil réis mensais. As três casas foram arrematadas pelo próprio Felix Garcia, o credor, que adicionou 250 mil réis à avaliação, totalizando 1:500\$000. Muito provavelmente Garcia tenha logrado abater do valor das propriedades seu quinhão da dívida. ${ }^{23}$

Francisco Xavier e sua esposa haviam portanto investido suas economias em imóveis para aluguel, acumulando um patrimônio leiloado por 2:901\$000 réis e se dando ao luxo de manter uma das casas fechada. Se esta quantia não o colocava entre os mais ricos da cidade, entre os pescadores a situação era diferente. ${ }^{24}$

Através das listas de qualificação eleitoral foi possível ter uma noção da renda dos pescadores. A Constituição de 1824 estabeleceu eleições indiretas para as Assembleias Provinciais, Câmara dos Deputados e Senado, distinguindo "simples votantes" de elegíveis. No primeiro turno, os simples votantes escolheriam entre os elegíveis os eleitores, que em etapa subsequente votariam nos representantes do povo. O voto era censitário, tanto para votantes quanto para elegíveis. Entre 1846 e 1881, o mínimo exigido para ser votante era 200 mil réis anuais. Como percebeu Aldrin Castellucci, "não eram [valores] suficientemente elevados a ponto de impedir a qualificação de pessoas relativamente pobres que aspirassem direitos de cidadania. Além disso, tais rendas podiam ser apenas declaradas, dispensando-se ou sendo flexível sua comprovação". Nesses casos, o procedimento usual foi registrar uma renda baixa, na grande maioria das vezes a quantia de 300 mil réis, portanto, pouco acima da mínima. Em contrapartida, era-se mais rigoroso com a comprovação da renda mínima para ser elegível - 400 mil réis - o que excluía a maior parte dos trabaIhadores. Se apenas uma minoria alcançava status de elegível, a situação era ainda mais crítica no caso dos pescadores, que estavam entre as categorias com menor média de salário. Apenas 3,6\% deles puderam fruir desse status. ${ }^{25}$

\section{Gráfico 3 - Renda dos pescadores (em mil réis anuais)}

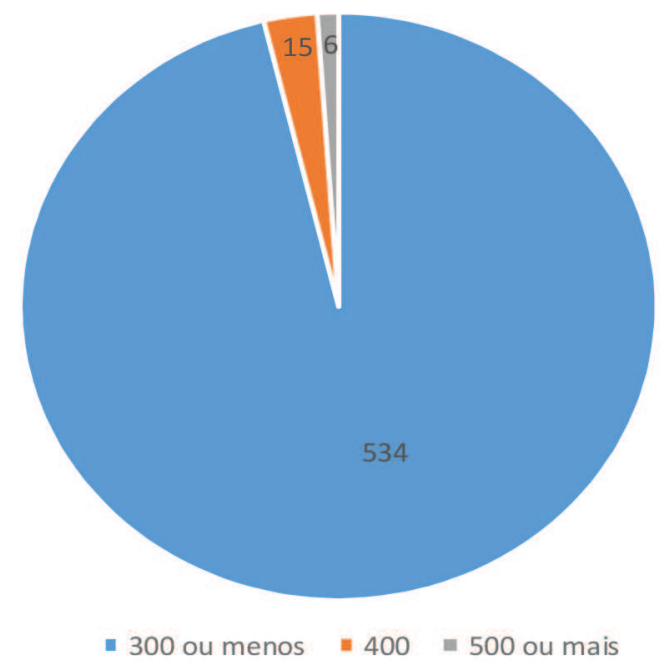

Fonte: Listas Eleitorais, 1853-1880.

23 APEBa, inventário de Apolinária Maria de Santana, 01/09/1869. Infelizmente a documentação não revela o tamanho da dívida nem quanto sobrou após a quitação para ser partilhado pela família.

24 Com esse patrimônio, Francisco Xavier estava fora do grupo dos 40\% mais ricos da sociedade. Pelos critérios de riqueza estabelecidos por Katia Mattoso, sua fortuna se caracterizaria como "média”, o quarto nível de riqueza em uma escala ascendente com oito. MATTOSO. Bahia, Século XIX, p. 608.

25 AHS e APEBa, Listas Eleitorais. A exceção era a llha de Maré, onde o mínimo exigido foi de 200 mil réis e, curiosamente, dois pescadores conseguiram se qualificar declarando rendas inferiores, de 180 e 100 mil réis. CASTELLUCCI, Aldrin A. S. Trabalhadores, máquina política e eleições na primeira república (Tese de Doutorado em História, Universidade Federal da Bahia, 2008), p. 24. Grifo no original. 
O patrimônio de Francisco Xavier é um indício de que ele estaria entre a minoria que ganhava acima de 500 mil réis. O aluguel de duas de suas casas por si só já garantia 240 mil réis por ano, mais da metade do necessário para entrar no seleto grupo de pescadores elegíveis. Acreditava, portanto, que essa condição gerava inveja da imensa maioria de pescadores ao seu redor, que se encontrava em situação material menos saudável, ganhando abaixo de 300 mil réis ou menos. ${ }^{26}$

Desigualdade econômica não é ingrediente suficiente para conflito social, contudo. E os oponentes de Xavier certamente tiveram motivações outras que a invídia de sua fortuna. Não foram raros os casos de disputa territorial entre pescadores, na maior parte das vezes com condições financeiras semelhantes. Na regra pesqueira, cada lugar teria seus donos, os "de dentro da comunidade", sendo restrito o uso pelos "de fora”. Não parece ser o caso de Francisco Xavier, porém. Suas posses no Rio Vermelho indicam que ele não chegara recentemente. Poderia contudo ser um tipo distinto de "outsider". Se foi ele mesmo o redator das petições, Xavier seria não só letrado como loquaz, alguém que caprichava na retórica em suas solicitações: "O Representante, excelentíssimo Senhor, bem que [poderia ser] lacônico em sua exposição, porém alguma prolixidade [se faz] necessária para bem fundamentar a sua queixa, e [assim obter] de Vossa Excelência Justiça, Justiça com que Vossa Excelência sempre [carrega os] seus atos". Contrastaria com os $82 \%$ de pescadores do Rio Vermelho que não sabiam ler e escrever. ${ }^{27}$

Seria então "de fora" no sentido cultural do termo? Alguém que não era pescador "de nascença", pobre como os demais, mas com acesso à cultura letrada e recursos materiais e que resolveu adentrar naquele disputado mundo tendo, por ser quem era, acesso negado ao mar? É possível. Mas suspeito que o cerne do conflito estivesse no arranjo das relações de trabalho. Aprendamos então um pouco de pesca.

Lembremos dos equipamentos de Xavier, canoa e rede estimados em 600 mil réis. A rede que possuía era de calão, utilizada para cerco em águas rasas. Sobre a importância desse tipo de rede em comunidades pesqueiras baianas, nos diz John Cordel:

\begin{abstract}
Uma rede de calão [ ] normalmente representa o investimento de todas as economias de um mestre. Poucas redes são compradas novas e são frequentemente herdadas em vários estágios de uso, necessitando de consertos contínuos. Possuir tal rede é a mais alta aspiração de um pescador e demonstra a marca de um status social elevado. ${ }^{28}$
\end{abstract}

Xavier possuía sozinho um equipamento que lhe conferia status e cujo valor equivalia a, no mínimo, dois anos de trabalho da imensa maioria dos pescadores. Não só isso; tendo-o perdido no incêndio, não teve dificuldade em repô-lo, uma vez que aparece com nova rede e canoa menos de um ano depois.

26 A proporção para os pescadores do Rio Vermelho é muito semelhante à dos pescadores em geral, sendo esta: $96,2 \%$ ganhando até $300,2,7 \%$ com 400 e 1,08\% acima de 500 mil réis. Entre os pescadores da freguesia de Brotas a proporção é de 92,9\%, 5,4\% e 1,8\% respectivamente. AHS e APEBa, Listas Eleitorais.

27 APEBa, Petição de Francisco Xavier de Santana ao presidente da província. AHS, Lista eleitoral Brotas.

28 CORDELL, John. "Marginalidade social e apropriação territorial marítima na Bahia”. In: DIEGUES, A. C. e MOREIRA, A. (orgs). Espaço e recursos naturais de uso comum. São Paulo: Nupaub/USP, 2001, p. 4 e 5. As comunidades que Cordell pesquisou são do século XX, mas as lógicas aparentam ser antigas. 
A rede de calão era valiosa porque sofisticada. Bastante comprida, feita de algodão entralhado à piaçava, tinha de ser infundida por casca de mangue vermelho a cada oito dias para a sua conservação. Tinha pequenas boias na parte de cima e uma grande ao centro, chamada "capitão", servindo para manter a rede em suspensão. Na parte de baixo iam presas a fazer peso pequenas esferas de barro cozido, os "bolos". Seu uso mais comum era de certa complexidade, requeria duas canoas e oito homens com preestabelecida divisão de trabalho. ${ }^{29}$

Com a rede embarcada, iam os homens ao mar à procura de cardumes. Uma vez encontrado, lançavam ao mar a rede, presa a uma ponta da canoa. Começavam a circular o cardume com a canoa, moldando neles a rede em formato de círculo. Enquanto isso, a segunda canoa se amarrava e seguia direção contrária, até fechar a circunferência. Daí mergulhavam dois ou três homens para unir as pontas da rede, enquanto outros dois, os "apontadores", uniam a parte de baixo. Em caso de qualquer resistência em baixo por conta de uma pedra ou outra coisa, mergulhavam os "abaixadores", que percorriam toda a parte inferior da rede, pela parte de dentro ou de fora, levantando os pesos e livrando-a dos obstáculos. Ela era, por fim, recolhida e as canoas voltavam a terra.

Para se tocar com segurança atividades coletivas como essa dentro das águas era preciso forte hierarquia, visto que, em um momento de risco, não se dispunha de tempo para discutir o que fazer. A palavra do mestre era a lei e a relação dos pescadores para com ele deveria ser de respeito, não apenas por ser dono do equipamento, mas pelo seu saber destacado. Se estivera envolvido em relações hierárquicas com outros pescadores, Xavier parecia ter perdido o respeito. Talvez fosse um mestre arrogante ou autoritário, quem sabe fosse incompetente. ${ }^{30}$

Há outra possibilidade. Existia um uso alternativo da rede de calão, com proceder consideravelmente mais simples. Uma extremidade da rede era amarrada na terra e a outra na ponta da canoa. A canoa ia ao mar a partir de um ponto na beira da água que permitisse à rede estar esticada. De lá, fazia um semicírculo varrendo o mar até chegar novamente à areia, do lado oposto de onde saíra. Em que pese a quantidade menor de peixes assim obtidos, esta modalidade tinha a vantagem de necessitar apenas de um homem e uma única canoa.

Assim, é possível que Xavier tivesse optado por fazer sua pescaria só, fosse pela simplicidade ou pela gana de se apropriar sozinho de todo o resultado da faina. Nesse sentido, seus oponentes se veriam combatendo alguém que, na visão deles, pescava de modo egoísta, sem dar a chance a outros pescadores de partilhar daquela atividade. Teríamos portanto um conflito entre uma empresa individualista e formas coletivas de trabalho, uma quebra da solidariedade e talvez subversão do costume local. Neste caso, a destruição dos instrumentos de trabaIho de Xavier pode ter tido este aspecto político, sendo um equipamento marcadamente coletivo que estava sendo usado de modo mesquinho.

29 BPEB. "A pesca na Bahia”.

30 Sobre a questão da mestrança: MALDONADO, Simone Carneiro. Mestres e mares: espaço e indivisão na pesca marítima, São Paulo: Annablume, 1993, p. 129-63. 


\section{Aspectos políticos}

Mas pode ter havido política no sentido mais convencional. Uma quantidade expressiva de pescadores estava envolvida com o processo eleitoral. Um estrato consideravelmente menor deles podia tentar fazê-lo de modo mais direto, qualificando-se para a votação como elegíveis. Como vimos, apenas um em cada trinta pescadores possuía renda suficiente para tal. Nas minhas listas, apenas seis conseguiram com relativa folga. Barnabé do Coração de Jesus, da freguesia de Brotas, Leopoldino José Fernandes e Severiano Nonato de Santana, ambos da Conceição da Praia, declararam renda de 600 mil réis anuais. Também da Conceição da Praia, temos Francisco Rodrigues Soares com renda de 800 mil réis e Joaquim José de Santana Barbosa, com 1 conto de réis. Por fim, Domingos Ribeiro Guimarães Lopes, o pescador mais afortunado encontrado até agora, com renda anual de 2 contos de réis. Era o único elegível da Ilha de Maré, que tinha 174 pescadores qualificados. ${ }^{31}$

Tabela 5 - Pescadores elegíveis por freguesia (1853-1880)

\begin{tabular}{c|c|c|c|c|c}
\hline & Itapuã & Ilha de Maré & Vitória & Brotas & $\begin{array}{c}\text { Conceição da } \\
\text { Praia }\end{array}$ \\
\hline Elegível & $1(0,5 \%)$ & $1(0,6 \%)$ & $7(6,7 \%)$ & $4(7,1 \%)$ & $7(77,8 \%)$ \\
\hline Não elegível & $193(99,5 \%)$ & $173(99,4 \%)$ & $98(93,3 \%)$ & $52(92,9 \%)$ & $2(22,2 \%)$ \\
\hline
\end{tabular}

Fonte: Listas Eleitorais, 1853-1880.

Alguns fatores pareciam significativos para ascender socialmente e, por conseguinte, alcançar a possibilidade de participação política plena em termos eleitorais. O estado civil era um deles. A proporção de elegíveis entre pescadores que eram ou haviam sido casados era mais que o dobro do que entre os solteiros. Entre os que sabiam ler, $16 \%$ eram elegíveis; entre os analfabetos, apenas $3 \%$. Por fim, o local onde moravam também influía. ${ }^{32}$

Como é de se esperar, de modo geral, quanto mais próspera a povoação, maior a proporção de elegíveis. Assim, Itapuã e Ilha de Maré se equivalem com baixa proporção, enquanto Vitória e Brotas pareiam com um percentual um pouco maior. O que ainda está por se explicar é a diferença absurda de todas elas para Conceição da Praia, onde sete dos nove pescadores qualificados eram elegíveis. A pequena quantidade de qualificados pode ter ajudado a distorcer para cima o percentual, mas, de todo modo, naquela comunidade estava presente um terço de todos os pescadores elegíveis discriminados em lista, o que é em si significativo.

A participação política não estava contudo restrita ao processo eleitoral. Os pescadores podiam ter relações com pessoas influentes politicamente, fazer pressão sobre as autoridades para atender às suas demandas e até fazer parte de grupos políticos. Voltemos ao caso de Xavier, sua canoa e sua rede.

Em sua carta ao presidente da Província, de agosto de 1863, Francisco Xavier procurou dar contornos partidários ao seu caso. Seu mau agouro decorria da "preponderância de um Partido que tão desapiedadamente dominou por tanto tempo o País". Referia-se ao Partido Conservador, que saíra recentemente do poder, após estar no comando pelo longo período que foi de 1848 a 1861 - desconsiderando-se

31 AHS e APEBa, Listas Eleitorais.

32 AHS e APEBa, Listas Eleitorais. As cinco freguesias da tabela foram as únicas que possuíam pescadores listados dentre as que discriminavam eleitores de simples votantes. 
os anos de conciliação (1853-1856). No ano em que contava sua história, estava no poder nacional o Partido Progressista, fruto do período de conciliação, mistura de antigos políticos liberais e conservadores dissidentes. ${ }^{33}$

Àquela época ocupava o cargo de presidente da Província da Bahia o pernambucano Antônio Coelho de Sá e Albuquerque, com 42 anos de idade incompletos e pouco menos de um ano no Palácio do Governo. ${ }^{34}$ Não descobri qual o partido de Sá e Albuquerque, mas o tom escolhido por Francisco Xavier para dialogar com ele indica que não pertencesse aos conservadores. Como era cargo indicado pelo poder central, é provável que pertencesse ao recém-criado Partido Progressista. É evidente que o pescador tentava em sua retórica insuflar o presidente da província com sentimentos de rixa partidária a fim de ganhá-lo para a sua causa. É possível que estivesse insinuando que o povoado do Rio Vermelho fosse um curral político conservador e ele, liberal, teria sido vítima de violência política de apoiadores do antigo regime.

Não é de se descartar que Xavier tivesse mesmo algum grau de afinidade ideológica com o partido do poder. Em sua oposição aos conservadores, os progressistas enfatizavam a necessidade de se reformar a legislação visando corrigir problemas de organização e processos judiciários. Defendiam a proteção dos direitos individuais frente a um Estado centralizador e com uma legislação desnecessariamente controladora para aquela época de paz imperial. ${ }^{35}$ Ideias que deviam soar bem aos ouvidos de um pescador que foi durante muito tempo impedido de exercer seu ofício por conta de exigências e controles legais. No mínimo, Xavier deve ter avaliado que membros desse partido tenderiam a discordar dos procedimentos pelos quais ele estava passando.

De todo modo, há indícios de relações políticas permeando o caso. Segundo Xavier, os seus antagonistas promoviam desordens contra ele por julgarem estar "apadrinhados por um lado a que de pronto se prestaram, e que apelidaram de Carramanchão". Em um dicionário do século XVIII, localizei o verbete caramanchão (com um " $r$ " apenas), significando um artefato de ripas sustentando plantas trepadeiras a fim de fazer sombra. Até hoje a palavra é utilizada com a mesma significação. Talvez a referência fosse a uma pessoa influente politicamente que possuía um caramanchão ou, quem sabe, a um grupo político que os protegesse, como o carramanchão protege do sol e outras intempéries. ${ }^{36}$

E não era um apoio às escondidas, era abertamente declarado. Pelo menos assim relata Xavier, na época em que haviam ressuscitado a postura que o fez ter sua pesca proibida. Segundo ele, "se antes desta publicação, [ ] o ânimo daquele povo se achava exacerbado contra o Representante, [ ] este exacerbamento ainda mais cresceu a ponto de proclamarem altamente que tudo haviam vencido porque tinham o Caramanchão por si".

Xavier bem poderia estar mentindo, inventando uma conspiração política

33 CARVALHO, José Murilo de. A construção da ordem: a elite política imperial. Brasília, Ed. Universidade de Brasília, 1981, p.158 e 170.

34 Apesar da pouca idade e curto tempo no cargo, Sá e Albuquerque era um político com experiência. Antes de ser $027^{\circ}$ presidente da Bahia, fora presidente das províncias da Paraíba do Norte, Alagoas e Pará, além de ter ocupado outros cargos públicos. WILDBERGER, Arnold. Os presidentes da província da Bahia, efetivos e interinos, 1824-1899. Salvador. Typographia Beneditina, 1949, p.449-451.

35 CARVALHO. A construção da ordem, p.159.

36 APEBa, Petição de Francisco Xavier de Santana ao presidente da província. BLUTEAU, Raphael. Vocabulario portuguez \& latino: aulico, anatomico, architectonico... Coimbra, Collegio das Artes da Companhia de Jesus, 1712-1728. 8 v, verbete "caramanchão". "Construção ligeira, espécie de pavilhão de ripas, canas ou estacas, revestidas de trepadeiras, nos jardins". FERREIRA, Marina Baird \& ANJOS, Margarida dos (coord.), Novo dicionário Aurélio da língua portuguesa. Curitiba: Positivo, 2009, verbete "caramanchão". 
para se colocar como perseguido. Mas seus inimigos de fato aparentavam estar articulados politicamente. Afinal, tinham conseguido por mais de uma vez usar os poderes públicos a seu favor e com certa rapidez. Haviam conseguido até mesmo reeditar em uma grande tipografia uma postura que serviria para o seu embate.

Poderíamos pensar que Xavier pertencesse de fato a um grupo político oposto ao povo do Carramanchão e que toda essa disputa fosse em última análise um confronto de grupos políticos rivais. Mas se assim o fosse, por que ele não teria acionado seus correligionários durante todo esse tempo? Por que ir sozinho ao presidente da Província? Não acredito que a causa tenha sido política. Penso que uma vez estabelecido o conflito entre Xavier e demais pescadores, ambas as partes procuraram usar as armas que tinham à disposição, e na esfera política os inimigos de Xavier estavam à frente do próprio, que aparentava estar sozinho na luta.

Daí a importância de se criar redes sociais e políticas junto com as de pesca. $O$ próprio Xavier construiria as suas com o tempo, talvez pensando em ganhar força dentro de sua comunidade. À época do inventário de seus bens, uma de suas casas aparece como alugada a Manoel Nicolau da Conceição, que por sua vez aparece nas listas de qualificação de 1876, onde descobrimos também ser pescador. Diz-se que morava no $22^{\circ}$ quarteirão, possivelmente ainda na mesma casa que um dia fora de Xavier. Era casado, não sabia ler e declarou renda mínima, sendo simples votante. Tinha naquele momento 50 anos, sendo portanto mais novo que Xavier, que já estaria com mais de $60 .{ }^{37}$

Além do inquilino, outros pescadores apareceram em suas relações. Sua fiIha, Maria dos Passos, casou-se com Umbelino Gomes da Boa Morte, que não só era pescador, como também filho de um, ambos moradores do $23^{\circ}$ quarteirão. Tinha em 1876 trinta e sete anos, sabia ler e escrever e possuía renda anual de 400 mil réis, o que o credenciou a participar do processo de votação como elegível. Assim também fez seu pai, Manoel Gregório Gomes Correa, com renda igual à de Umbelino, estando casado e com 54 anos completos naquele ano..$^{38}$

Portanto, Xavier casou sua filha com uma família pesqueira. E não eram quaisquer pescadores, uma vez que Umbelino e o pai Manoel estavam entre os poucos elegíveis da comunidade: eram somente 4 dos 56 pescadores qualificados na freguesia. Com o casamento, Xavier se ligava a uma família de pescadores possivelmente com importância local e algum grau de relevância política.

\section{Considerações}

Neste artigo procurei traçar características gerais dos pescadores na cidade de Salvador, como cor, idade, condição civil, relação com a escravidão, participação política, lógicas de moradia. Pescadores em Salvador moravam próximos à praia, onde pescavam majoritariamente em canoas, embarcações propícias para curtos deslocamentos. Viviam próximos uns aos outros em pontos específicos da enorme orla da cidade, em vilas de pescadores, nas quais estabeleciam relações de trabalho, amizade, compadrio e família. Entender e manejar essas relações era fundamental para sobreviver no mundo da pesca, com sua dura realidade em que

37 APEBa, Inventário de Apolinária Maria de Santana. e AHS, Lista eleitoral de Brotas.

38 AHS, lista eleitoral de Brotas. Além de Umbelino e seu pai, há numerosas ocorrências de pai e filho pescadores, irmãos pescadores e outros parentescos. Isso indica uma tendência de transmissão familiar da atividade pesqueira. 
baixos rendimentos e a dependência de meios de produção de outrem eram a regra.

O caso de Francisco Xavier de Santana é sugestivo nesse sentido. Mesmo dono de seus meios de produção e cumprindo todos os requisitos formais para pescar em um mar que era juridicamente aberto a qualquer um, foi constantemente contestado e confrontado. Ter laços comunitários e políticos podia ser tão ou mais importante que recursos materiais para se estabelecer e ascender naquele meio. Talvez por isso, não tenha encontrado qualquer notícia que o envolvesse depois do casamento de sua filha. Com o casamento da filha, quem sabe, ele tenha definitivamente se inserido na comunidade, conseguido equilibrar o jogo e, a partir daí, exercido sua pesca em paz.

Recebido em 20/06/2015

Aprovado em 21/12/2015 